\title{
Aerobic Program in Persons with Stroke: A Systematic Review
}

\author{
Treino Aeróbico em Indivíduos após Acidente Vascular Cerebral: \\ Uma Revisão Sistemática
}

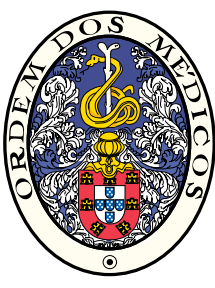

\author{
Juliana V. FRANCICA ${ }^{1}$, Aline BIGONGIARI ${ }^{2}$, Luis MOCHIZUKI ${ }^{2}$, Maria Luiza J. MIRANDA ${ }^{1}$, Bruno RODRIGUES ${ }^{1}$ \\ Acta Med Port 2014 Jan-Feb;27(1):108-115
}

\section{ABSTRACT}

Introduction: The aim of this study was to perform a systematic review on the exercise trials post stroke.

Material and Methods: Therefore, we conducted a systematic review of randomized controlled clinical trials published in PubMed and PEDro. The inclusion criteria were: Studies - randomized or controlled clinical trials; Participants - Adults of any age with a clinical diagnosis of stroke; Interventions - any aerobic physical training aimed at improving cardiovascular capacity and/or function. Two independent reviewers categorized the selected trials, assessed methodological quality and extracted the relevant data. Various protocols were analyzed and used for both the assessment and physical training of post-stroke subjects.

Results: According to clinical trials analyze, a wide range of instruments were used to measure functional capacity. Ergospirometry and ergometry were found to be main devices in the assessment of cardiovascular capacity. Cycle ergometer training was the most commonly used training strategy, and conventional physiotherapy (based on stretching, strengthening, balance, coordination and gait training) was the most frequent control therapy.

Discussion: Training duration ranged from 4 weeks to 6 months; the mean weekly frequency was 3 sessions per week while training intensity ranged from 40 to $80 \%$ of maximal heart rate or VO2 peak. Duration of training sessions ranged from 25 minutes to 1 hour.

Conclusion: Exercise training is a promising tool for the management of post-stroke patients, both in terms of improved cardiovascular and functional capacity. Further studies are needed to widen the scope of therapeutic management of this population.

Keywords: Exercise; Stroke; Walking; Exercise Therapy.

\section{RESUMO}

Introdução: O objetivo deste estudo foi realizar uma revisão sistemática sobre o exercício após acidente vascular cerebral

Material e Métodos: Para isso, foi realizada uma revisão sistemática de ensaios clínicos randomizados e controlados publicados no PubMed e PEDro. Os critérios para inclusão dos artigos foram: Estudos - ensaios clínicos randomizados ou controlados; participantes adultos de qualquer idade com diagnóstico clínico de acidente vascular cerebral; intervenções - qualquer treino físico aeróbio que vise melhorar a capacidade e/ou função cardiovascular. Dois revisores independentes categorizaram os ensaios selecionados, avaliaram a qualidade metodológica e extraíram os dados relevantes. A análise realizada foi dos vários protocolos usados tanto para a avaliação e treino de indivíduos pós-acidente vascular cerebral.

Resultados: De acordo com estudos clínicos analisados, uma vasta gama de instrumentos foi utilizada para medir a capacidade funcional dos pacientes. Ergometria e ergoespirometria foram os principais dispositivos da avaliação da capacidade cardiovascular. Treinolexercício na bicicleta ergométrica foi a estratégia de treino mais comumente usada, e fisioterapia convencional (baseada em alongamentos, fortalecimentos, treino de equilíbrio, coordenação e marcha) foi a terapia de controle mais frequente.

Discussão: A duração do programa variou de 4 semanas a 6 meses, a frequência semanal média foi de três sessões por semana, enquanto que a intensidade do treinamento variou de 40 a $80 \%$ da frequência cardíaca máxima ou VO2 máximo. A duração de sessões de treino variou entre 25 minutos a 1 hora.

Conclusão: O treino físico é uma ferramenta promissora para o tratamento de pacientes pós-AVC, tanto em termos de melhoria da capacidade funcional e da capacidade cardiovascular. No entanto, mais estudos são necessários para ampliar a área de atuação terapêutica nesta população.

Palavras-chave: Exercício Físico; Acidente Vascular Cerebral; Marcha.

\section{INTRODUCTION}

Stroke is the third most common cause of mortality in developed countries ${ }^{1}$ and a leading cause of a permanent disability. ${ }^{2}$ The long-term disability and institutionalization of stroke sufferers pose a substantial economic burden in many countries. ${ }^{3}$ For this reason, it is necessary further effective rehabilitation programs to improve the recovery of functional status and quality of life of individuals who have suffered a stroke. ${ }^{4}$

Several disabilities potentially follow stroke, including loss of motor, sensory and cognitive functions. ${ }^{1}$ Hemiparesis is the main neurologic deficit, affecting an estimated
$85 \%$ of acute stroke patients. ${ }^{5}$ In most of these individuals, hemiparesis persists after 6 months of the onset, often resulting in impaired mobility and sedentary lifestyle..$^{5}$ Considering the motor sequelae, most studies have focused primarily on restoration of motor control and independence of the affected subject. However, the majority of post-stroke individuals also suffer from cardiac patology, ${ }^{6}$ and have low exercise capacity as a consequence of immobility. ${ }^{7}$

The physical and functional benefits of stroke survivors' engagement in various types of physical activity are now well established. These benefits may include improved

1. Human Movement Laboratory. São Judas Tadeu University. São Paulo/SP. Brazil.

2. Biomechanical Laboratory. University of São Paulo. São Paulo/SP. Brazil.

Recebido: 09 de Outubro de 2013 - Aceite: 10 de Janeiro de 2014 | Copyright @ Ordem dos Médicos 2014 


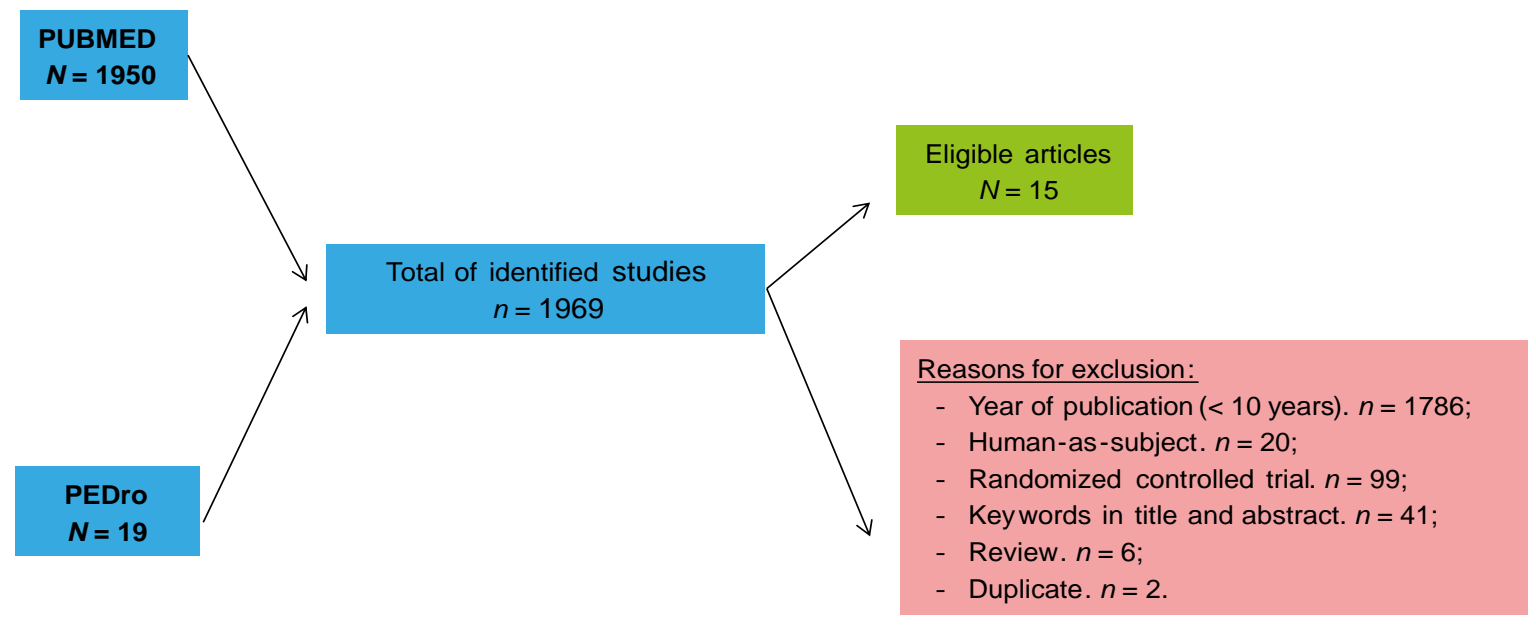

Figure 1 - Flow chart demonstrating search strategy and exclusion criteria

recovery, function and various aspects of fitness. As a result, group exercise classes are emerging as a valuable strategy to promote engagement in regular exercise. ${ }^{8}$

Hill et $\mathrm{al}^{9}$ have argued that one factor limiting the incorporation of aerobic exercise into rehabilitation programs is the difficulty in obtaining an exercise stress test from a stroke patient. Neurologic deficits in gait and balance after stroke often preclude exercise testing and training using traditional equipment such as treadmills and cycle ergometers. For this reason, adapted testing protocols and exercise training programs have been developed to evaluate the exercise tolerance e to promote physical benefits in patients after stroke.

Taking into account the range and effectiveness of different training and physical capacity evaluation protocols in the literature, we decided to analyze the literature in this area to survey the techniques and procedures applied in stroke rehabilitation.

\section{MATERIAL AND METHODS}

A systematic literature review was conducted from August through January 2013, using the PubMed (a service of the U.S. National Library of Medicine and the National Institutes of Health) and PEDro (Physiotherapy Evidence Database) electronic databases. The PEDro has free access, facilitating the use by professionals, students and researchers in the area. It is available in five languages: English, Mandarin, French, German and Portuguese, and offers a simple version without technical terms to consumers of physiotherapy services. The findings included the articles that contained the key words: 'Stroke' [Mesh] AND 'Physical Training' AND 'Aerobic' .

During the search, the 1950 studies observed presented quite different and sometimes conflicting results, so we decided to narrow our scope to the articles that a) dealt with the evaluation protocols for post-stroke aerobic training; b) used randomized controlled trials; c) were published in English; d) were published in the last 10 years (01/2002 to $10 / 2012$ ); e) used only humans as research subjects; f) and had keywords in the title and/or abstract. Additionally, studies which failed to adequately describe the characteristics of the evaluation or physical training were excluded. For the selection of articles, the compatibility between titles and abstracts of articles was independently analyzed by two researchers. Each researcher created a single list with a written justification for either inclusion or exclusion of articles, and the two lists were then compared and analyzed by a senior researcher who determined the potential relevance of the articles

This was followed by the reading of the articles in full, and two researchers independently performed data extraction of information about authorship, country of origin, journal title, country of journal, year of publication, impact factor of journal, and methodology used for evaluation and physical training.

When we performed the first key word search in PubMed, we obtained a total of 1950 articles. This number fell to 165 when the 10 years of publication criteria was applied and to 145 when human-as-subjects requirement was addressed. After the criteria of randomized controlled trials and availability in English were applied the number of articles dropped to 46 . Of these, 32 failed to meet the criteria of key words in the titles and abstracts. The remaining 14 articles fully met our inclusion criteria.

When keyword search was performed using the PEDro, 19 articles were selected, of which 6 were excluded because they were reviews, 9 because they lacked keywords in the title or abstract (mismatch with the research topic), 2 because they had appeared previously on our PubMed search, and 1 was excluded because it was published in 1999. Only one study could be used for analysis (Fig. 1).

\section{RESULTS}

When analyzing the authorship of articles, we found that all studies had multiple authors. $33.3 \%$ were written by 4 authors, $20 \%$ by 5 authors, $20 \%$ by 7 authors, and $13 \%$ by 8 authors, with an average $5.1 \pm 1.8$ authors per article. Country of origin was quite heterogeneous but UK and 
American journals largely prevailed as sites of publication. These data are shown in Table 1.

The most commonly found protocols for assessment of cardiovascular performance used three instruments which are well known in clinical practice: the six minutes walking test (6MWT - 5 studies) ergometry ( 7 studies) and ergospirometry (8 studies). The articles showed a concern for quantifying not only the cardiorespiratory but also the functional ability of patients and for this purpose they used a series of tests designed to measure different functions, such as the Force Platform (one study), the Berg Balance Scale (4 studies), the Rivermead Mobility Index (3 studies), the French Activities Index (FAl - 2 studies), the Fugl-Meyer Sensorimotor Test (1 study), the Get up and Go (GUG 1 study), the Functional Independence Measure (FIM - 3 studies), motor assessment scale (1 study), and the Functional Ambulation Category (FAC - 2 studies). These data are shown graphically in Fig. 2 .

For a better understanding of the assessment protocols used in the studies analyzed, we chose to divide the results into: 1) Population characteristics (time of stroke, sample, age and gender); 2) Protocols of aerobic training (training duration, weekly frequency, intensity, duration of sessions, type of training); and 3) Main results. Looking at the evaluation protocol, we found that all studies were randomized controlled trials, with one group being selected for aerobic training, and the other as a control group. As to the instruments used for aerobic training, we observed that $60 \%$ of studies used cycle ergometer, $33.3 \%$ used a treadmill and $6.7 \%$ a combination of the two. With regard to control group, $73.3 \%$ of studies used the conventional physiotherapy as a therapeutic option, $6.7 \%$ used functional training, and $20 \%$ had chosen alternative protocols, ${ }^{10-12}$ which are shown in Table 2.

We also observed that the total duration of the training ranged between 4 weeks and 6 months $(6.7 \%-4$ week / $20.1 \%$ - 6 weeks / $20.1 \%$ - 8 weeks / $6.7 \%$ - 10 to 12 weeks / 6.7\% - 3 months / 6.7\% - 14 weeks / $20.1 \%$ - 6 months). Regarding weekly frequency, in 9 studies the subjects underwent $3 \mathrm{x} /$ week training, while in 3 studies subjects underwent $5 x /$ week training. As to exercise intensity, 6 studies used fixed values, $40 \%$ ( 1 study), 60\% (4 studies) and $70 \%$ (1 study) of maximal HR or VO2 peak. Other studies have chosen progressive load ranging from $50-60 \%$ (1 study),

Table 1 - Description of author and journal characteristics of choice for publishing

\begin{tabular}{|c|c|c|c|c|c|}
\hline Study & $\begin{array}{c}\mathrm{N}^{\circ} \\
\text { Authors }\end{array}$ & $\begin{array}{c}\text { Country of } \\
\text { Author }\end{array}$ & Journal & $\begin{array}{l}\text { Country of } \\
\text { Journal }\end{array}$ & $\begin{array}{l}\text { Impact } \\
\text { Factor }\end{array}$ \\
\hline Globas et al ${ }^{15}$ & 8 & Switzerland & Neurorehabilitation and Neural Repair & USA & 4.495 \\
\hline Shin et $a^{14}$ & 5 & Korea & J Phys Ther Sci & Japan & 0.292 \\
\hline Toledano-Zarhi et al ${ }^{16}$ & 4 & Israel & NeuroRehabilitation & International & 1.635 \\
\hline Ivey et $\mathrm{al}^{17}$ & 4 & USA & Stroke & USA & 5.729 \\
\hline Quaney et al ${ }^{18}$ & 7 & USA & Neurorehabilitation and Neural Repair & USA & 4.495 \\
\hline Rimmer et al $^{13}$ & 5 & USA & Arch Phys Med Rehabil & USA & 2.282 \\
\hline Janssen et $a^{11}$ & 7 & Netherlands & Arch Phys Med Rehabil & USA & 2.282 \\
\hline Lee et $\mathrm{al}^{12}$ & 7 & Australia & JAGS & USA & 3.737 \\
\hline Lennon et al ${ }^{19}$ & 4 & Ireland & Clinical Rehabilitation & England & 2.123 \\
\hline Ivey et $\mathrm{al}^{20}$ & 5 & USA & Stroke & USA & 5.729 \\
\hline Katz-Leurer \& Shochina ${ }^{21}$ & 2 & Israel & NeuroRehabilitation & International & 1.635 \\
\hline Macko et $\mathrm{al}^{22}$ & 8 & USA & Stroke & USA & 5.729 \\
\hline Eich et $a^{10}$ & 4 & Germany & Clinical Rehabilitation & England & 2.123 \\
\hline Katz-Leurer et $\mathrm{al}^{23}$ & 3 & Israel & Clinical Rehabilitation & England & 2.123 \\
\hline Katz-Leurer et $\mathrm{al}^{24}$ & 4 & Israel & Arch Phys Med Rehabil & USA & 2.282 \\
\hline
\end{tabular}


A.

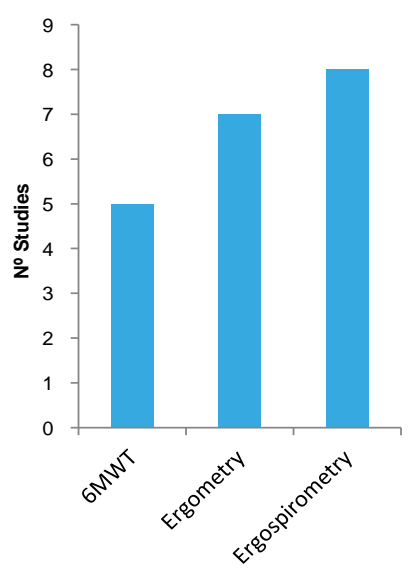

B.

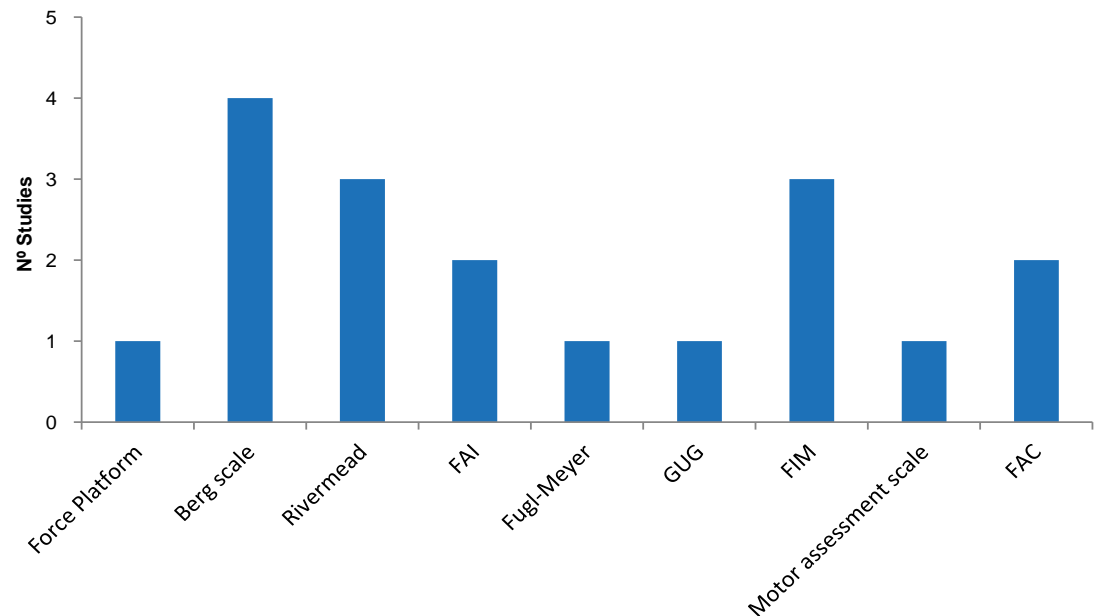

Figure 2 - A) Characteristics of evaluation protocol to determination of cardiorespiratory capacity; B) Characteristics of evaluation protocol to determination of functional capacity. Abbreviations: 6MWT = Six Minutes Walking Test; Berg scale = Berg Balance Scale; Rivermead = Rivermead Mobility Index; FAI = French Activities Index; Fugl-Meyer = Fugl-Meyer Sensoriomotor Test; GUG = Get up and Go; FIM = Functional Independence Measure; FAC = Functional Ambulation Category.

$50-70 \%$ (2 studies), $60-70 \%$ (3 studies) and $60-80 \%$ (1 study). However, when we observed session length, 8 studies chose 30 minutes fixed time (4 studies), 40 minutes ( 3 studies) and 45 minutes ( 1 study). Some researchers have chosen to create protocols with progression of time, such as 25-30 minutes ( 1 study), 30-50 minutes ( 1 study), 35-55 minutes ( 1 study) and 30-60 minutes ( 1 study). Three of the 15 studies had different time combinations, ${ }^{10,14,15}$ which can be seen in Table 2.

Concerning the main results presented, we observed: improvement in cardiorespiratory capacity (11 studies), walking speed ( 3 studies), as well as functional improvement ( 3 studies), increase in balance ( 2 studies) and in muscle strength ( 1 study). Only one study did not show any improvement after training proposed. Other benefits demonstrated were related to improved blood flow in the paretic muscles, improvement in hemodynamic and metabolic variables (Table 2).

\section{DISCUSSION}

Authorship analysis revealed a tendency towards multiple authorship. This can be explained by the complexity of the studies and their clinical nature, composed of samples involving a large numbers of subjects in both aerobic and conventional treatment. Of note was the heterogeneity of country of origin (at least 1 study by geographic continent), possibly due to the magnitude of chronic sequelae of stroke-associated morbidities, which has crossed borders and generated increasing interest in research involving new therapeutic approaches for the affected population. We also observed a tendency for authors to publish their experiments in American or UK journals, a fact that can be explained by the high impact factor of these journals, since these journals follow a tradition of strict scientific selection criteria, promoting greater visibility to the studies.

In the assessment of cardiorespiratory capacity, we identified three methods most used, the 6MWT, ergome- try and ergospirometry. However, we observed that the 5 studies using the 6MWT, occasionally used the results of this evaluation not to prescribe aerobic exercise, but as a parameter to measure the ability to walk, since the maximal HR data obtained from this evaluation was not taken into consideration for training prescription. However, different functional evaluations were used, and related to the specific objectives for each experiment. For example, the Berg Scale was most frequently used to balance evaluation, Rivermead Mobility Index for mobility, GUG for agility, FIM and FAC for functional independence, and Fugl-Meyer to evaluate sensorimotor characteristics.

The main tool used for aerobic exercise training was cycle ergometer, probably because it is generally regarded as safe for a population with critical balance deficits. Moreover, the choice of conventional physical therapy as control therapy is easy to understand, since in many situations it means a continuation of a treatment patients have been undergoing.

We were surprised to observe a mismatch between the periods, as $40.2 \%$ of articles reported short workouts (between 6 to 8 weeks) while 20.1\% reported much longer ones (6 months). We detected a somewhat regular cycle, whereby once short-term studies have been proposed, then immediately there was an attempt to replicate, or even to overcome, the same effects by using a long-term protocol. Likewise, studies using long-term protocols were followed by short-term protocol studies, and so forth.

According to our data analysis, we observed that 1 month of aerobic training promoted significant improvement in balance. However, aerobic training between 1 and 3 months of duration promoted increase of cardiovascular capacity, walking speed, balance, strength and improved quality of life. Six months of training induced additional benefits, such as improvement in hemodynamic and metabolic parameters. 
In most studies, subjects underwent a $3 x /$ week frequency of training, probably because this population presented important physical deconditioning, needing a rest period between one session and another for full physi- cal recovery. Regarding the duration of the session, it seems clear that, although many studies have chosen constant intensities (range 30-40 minutes), the majority opted for a progressive increase (range 25-60 minutes).

Table 2 - Description of type of study, population and aerobic training protocol characteristics, as well as summary of results

\begin{tabular}{|c|c|c|c|c|c|}
\hline STUDY & DESIGN & POPULATION & DURATION & INTERVENTION & RESULTS \\
\hline Globas et al ${ }^{15}$ & $\begin{array}{l}\text { Randomized controlled } \\
\text { trial } \\
\text { - Exercise group } \\
\text { - Control group }\end{array}$ & $\begin{array}{l}\text { Ischemic Stroke } \\
>6 \text { months } \\
\text { Middle cerebral } \\
\text { artery } \\
\mathrm{N}=38 \\
\text { Age }>60 \text { years } \\
\text { Male/ Female }\end{array}$ & $\begin{array}{c}3 \\
\text { months }\end{array}$ & $\begin{array}{l}\text { Exercise group } \\
3 \mathrm{x} / \text { week } \\
30-50 \mathrm{~min} / \text { session } \\
60-80 \% \text { HRR } \\
\text { Treadmill } \\
\text { Control group } \\
\text { Conventional } \\
\text { Physiotherapy }\end{array}$ & $\begin{array}{l}\uparrow \text { Peak } \mathrm{VO}_{2} \\
\uparrow \text { walking velocity } \\
\uparrow \text { balance } \\
\text { Improve in SF-12 }\end{array}$ \\
\hline Shin et al ${ }^{14}$ & $\begin{array}{l}\text { Randomized controlled } \\
\text { trial } \\
\text { - Combined exercise } \\
\text { group } \\
\text { - Conventional } \\
\text { exercise group }\end{array}$ & $\begin{array}{l}\text { Chronic stroke } \\
(6 \text { months }-5 \\
\text { years) } \\
N=21 \\
\text { Mean age }=57 \\
\text { years } \\
\text { Male/ Female }\end{array}$ & $\begin{array}{c}4 \\
\text { weeks }\end{array}$ & $\begin{array}{l}60 \text { min/ session } \\
5 x / \text { week } \\
\text { Combined exercise } \\
\text { group } \\
30 \text { min: functional } \\
\text { strength training } \\
30 \text { min aerobic } \\
\text { exercise: (40\%HRR) } \\
15 \text { min: treadmill } \\
15 \text { min: cycle } \\
\text { ergometer } \\
\text { Conventional } \\
\text { exercise group } \\
\text { Functional training }\end{array}$ & $\begin{array}{l}\text { Improvement in static } \\
\text { and dynamic balance } \\
\text { in both groups; } \\
\text { Greater improvement } \\
\text { in dynamic balance } \\
\text { in combined exercise } \\
\text { group. }\end{array}$ \\
\hline $\begin{array}{l}\text { Toledano-Zarhi } \\
\text { et } \mathrm{al}^{16}\end{array}$ & $\begin{array}{l}\text { Randomized controlled } \\
\text { trial } \\
\text { - Exercise group } \\
\text { - Control group }\end{array}$ & $\begin{array}{l}\text { Ischemic Stroke } \\
1-3 \text { weeks } \\
\text { Modified Rankin } \\
\text { Scale } \leq 2 \\
\mathrm{~N}=28 \\
\text { Mean age }=65 \\
\text { years } \\
\text { Male }\end{array}$ & $\begin{array}{c}6 \\
\text { weeks }\end{array}$ & $\begin{array}{l}\text { Exercise group } \\
3 \text { hours/week } \\
35-55 \text { min/session } \\
50-70 \% \text { HRmax } \\
\text { Upper cycle } \\
\text { ergometer } \\
\\
\text { Control group } \\
\text { Conventional } \\
\text { Physiotherapy }\end{array}$ & $\begin{array}{l}\text { None significant } \\
\text { difference between } \\
\text { groups, and previous } \\
\text { and post intervention. }\end{array}$ \\
\hline Ivey et $\mathrm{l}^{17}$ & $\begin{array}{l}\text { Randomized controlled } \\
\text { trial } \\
\text { - Exercise group } \\
\text { - Control group }\end{array}$ & $\begin{array}{l}\text { Ischemic stroke } \\
>6 \text { months } \\
\mathrm{N}=53 \\
\text { Mean age: } 62 \\
\text { years } \\
\text { Male/ Female }\end{array}$ & $\begin{array}{c}6 \\
\text { months }\end{array}$ & $\begin{array}{l}\text { Exercise group } \\
3 \times / \text { week } \\
40 \text { min/session } \\
60-70 \% \text { HRR } \\
\text { Treadmill } \\
\text { Control group } \\
\text { Conventional } \\
\text { Physiotherapy }\end{array}$ & $\begin{array}{l}\uparrow \text { Blood flow - paretic } \\
\text { side } \\
\uparrow \text { Cardiorespiratory } \\
\text { function (18\%) }\end{array}$ \\
\hline Quaney et al ${ }^{18}$ & $\begin{array}{l}\text { Randomized controlled } \\
\text { trial } \\
\text { - Exercise group } \\
\text { - Control group }\end{array}$ & $\begin{array}{l}\text { Ischemic Stroke } \\
<6 \text { months } \\
\mathrm{N}=38 \\
\text { Mean age }=58 \\
\text { years } \\
\text { Male/ Female }\end{array}$ & $\begin{array}{c}8 \\
\text { weeks }\end{array}$ & $\begin{array}{l}\text { Exercise group } \\
3 \text { x/week } \\
45 \text { min/session } \\
70 \% \text { HRR } \\
\text { Cycle ergometer } \\
\text { Control group } \\
\text { Conventional } \\
\text { Physiotherapy }\end{array}$ & $\begin{array}{l}\uparrow \text { VO2 peak, } \\
\text { processing velocity } \\
\text { and reaction, } \\
\text { strength and } \\
\text { accuracy during grip } \\
\text { test, gait velocity } \\
\text { and motor learn. }\end{array}$ \\
\hline
\end{tabular}


Table 2 - Description of type of study, population and aerobic training protocol characteristics, as well as summary of results (cont.)

\begin{tabular}{|c|c|c|c|c|c|}
\hline STUDY & DESIGN & POPULATION & DURATION & INTERVENTION & RESULTS \\
\hline Rimmer et al $^{13}$ & $\begin{array}{l}\text { Randomized controlled } \\
\text { trial } \\
\text { - Intensity group } \\
\text { - Duration group } \\
\text { - Control group }\end{array}$ & $\begin{array}{l}\text { Ischemic Stroke } \\
<6 \text { months } \\
\mathrm{N}=55 \\
\text { Mean age } 59.6 \\
\text { years } \\
\text { Male/ Female }\end{array}$ & $\begin{array}{c}14 \\
\text { weeks }\end{array}$ & $\begin{array}{l}\text { 3x/week (all groups) } \\
\text { Intensity group } \\
\text { Moderate intensity } \\
30 \text { min/session } \\
60-70 \% \mathrm{VO}_{2 \text { peak }} \\
\text { Cycle ergometer } \\
\\
\text { Duration group } \\
\text { Progressive intensity } \\
60 \text { min/ session } \\
40-70 \% \mathrm{VO}_{2 \text { peak }} \\
\text { Cycle ergometer } \\
\text { Control group } \\
\text { Conventional } \\
\text { Physiotherapy }\end{array}$ & $\begin{array}{l}\text { Intensity group } \\
\downarrow \text { SAP, DAP, } \\
\text { triglycerides } \\
\text { and total cholesterol } \\
\\
\text { Duration group } \\
\downarrow \text { triglycerides }\end{array}$ \\
\hline Janssen et $a^{11}$ & $\begin{array}{l}\text { Randomized controlled } \\
\text { trial } \\
\text { - Exercise group } \\
\text { - Control group }\end{array}$ & $\begin{array}{l}\text { Stroke } \\
>5 \text { months } \\
\mathrm{N}=12 \\
\text { Age } 54 \pm 10 \text { years } \\
\text { Male/ Female }\end{array}$ & $\begin{array}{c}6 \\
\text { weeks }\end{array}$ & $\begin{array}{l}2 \mathrm{x} / \text { week } \\
25-30 \mathrm{~min} / \text { session } \\
\text { Exercise group } \\
\text { (Cycling + maximally } \\
\text { tolerable to } \\
\text { electric stimulation) } \\
\\
\text { Control group } \\
\text { (Cycling + sensible } \\
\text { electric stimulation) }\end{array}$ & $\begin{array}{l}\uparrow \text { aerobic capacity } \\
\text { and functional } \\
\text { performance } \\
\text { after short aerobic } \\
\text { training. }\end{array}$ \\
\hline Lee et $\mathrm{al}^{12}$ & $\begin{array}{l}\text { Randomized controlled } \\
\text { trial } \\
\text { - Aerobic: cycle } \\
\text { training } \\
\text { - Progressive } \\
\text { resistance training } \\
\text { (PRT) }\end{array}$ & $\begin{array}{l}\text { Stroke } \\
>3 \text { months } \\
\mathrm{N}=52 \\
\text { Mean age }=63 \\
\text { years } \\
\text { Male/ Female }\end{array}$ & $\begin{array}{c}10-12 \\
\text { weeks }\end{array}$ & $\begin{array}{l}30 \text { sessions } \\
50-70 \% \mathrm{VO}_{2 \text { peak }} \\
30-60 \mathrm{~min} / \text { session } \\
\\
\text { 1) aerobic cycling } \\
\text { plus sham PRT } \\
\text { 2) sham cycling plus } \\
\text { PRT } \\
\text { 3) aerobic cycling } \\
\text { plus PRT } \\
\text { 4) sham cycling } \\
\text { plus sham PRT }\end{array}$ & $\begin{array}{l}\uparrow \text { aerobic capacity } \\
\text { Improve functional } \\
\text { performance, } \\
\text { but strength was not } \\
\text { different between } \\
\text { groups, as well as, } \\
\text { previous and post } \\
\text { intervention. }\end{array}$ \\
\hline Lennon et $a^{19}$ & $\begin{array}{l}\text { Randomized controlled } \\
\text { trial } \\
\text { - Exercise group } \\
\text { - Control group }\end{array}$ & $\begin{array}{l}\text { Ischemic Stroke } \\
>1 \text { year } \\
\mathrm{N}=48 \\
\text { Mean age }=60 \\
\text { years } \\
\text { Male/ Female }\end{array}$ & $\begin{array}{c}10 \\
\text { weeks }\end{array}$ & $\begin{array}{l}\text { Exercise group } \\
16 \text { sessions } \\
30 \mathrm{~min} / \text { session } \\
50-60 \% \text { HRR } \\
\text { Cycle ergometer } \\
\text { Control group } \\
\text { Conventional } \\
\text { Physiotherapy }\end{array}$ & $\begin{array}{l}\uparrow \mathrm{VO}_{2 \text { peak }} \\
\downarrow \text { cardiac risk score, } \\
\text { perception exertion, } \\
\text { major depression }\end{array}$ \\
\hline Ivey et al ${ }^{20}$ & $\begin{array}{l}\text { Randomized controlled } \\
\text { trial } \\
\text { - Exercise group } \\
\text { - Control group }\end{array}$ & $\begin{array}{l}\text { Ischemic Stroke } \\
<6 \text { months } \\
\mathrm{N}=46 \\
\text { Age }>45 \text { years } \\
\text { Male/ Female }\end{array}$ & $\begin{array}{c}6 \\
\text { months }\end{array}$ & $\begin{array}{l}\text { Exercise group } \\
3 \times / \text { week } \\
40 \mathrm{~min} / \mathrm{session} \\
60-70 \% \mathrm{HRR} \\
\text { Treadmill } \\
\text { Control group } \\
\text { Conventional } \\
\text { Physiotherapy }\end{array}$ & $\begin{array}{l}\uparrow 15 \% \mathrm{VO}_{2 \text { peak }} \\
\downarrow \text { insulin } \\
\text { Improvement in } \\
\text { glucose response }\end{array}$ \\
\hline
\end{tabular}


Table 2 - Description of type of study, population and aerobic training protocol characteristics, as well as summary of results (end)

\begin{tabular}{|c|c|c|c|c|c|}
\hline STUDY & DESIGN & POPULATION & DURATION & INTERVENTION & RESULTS \\
\hline Katz-Leurer et $\mathrm{al}^{21}$ & $\begin{array}{l}\text { Randomized controlled } \\
\text { trial } \\
\text { - Exercise group } \\
\text { - Control group }\end{array}$ & $\begin{array}{l}\text { Acute ischiemic } \\
\text { stroke } \\
N=64 \\
\text { Mean age }=62 \\
\text { years } \\
\text { Male/ Female }\end{array}$ & $\begin{array}{c}8 \\
\text { weeks }\end{array}$ & $\begin{array}{l}\text { Exercise group } \\
3 \mathrm{x} / \text { week } \\
30 \mathrm{~min} / \text { session } \\
60 \% \mathrm{HRR} \\
\text { Cycle ergometer } \\
\text { Control group } \\
\text { Conventional } \\
\text { Physiotherapy }\end{array}$ & $\begin{array}{l}\uparrow \text { endurance and } \\
\text { walking performance. } \\
\text { No significant } \\
\text { interaction effects } \\
\text { between autonomic } \\
\text { impairment } \\
\text { and training. }\end{array}$ \\
\hline Macko et $\mathrm{al}^{22}$ & $\begin{array}{l}\text { Randomized controlled } \\
\text { trial } \\
\text { - Exercise group } \\
\text { - Control group }\end{array}$ & $\begin{array}{l}\text { Stroke } \\
>6 \text { months } \\
\mathrm{N}=45 \\
\text { Age }>45 \text { years } \\
\text { Male/Female }\end{array}$ & $\begin{array}{c}6 \\
\text { months }\end{array}$ & $\begin{array}{l}\text { Exercise group } \\
3 \mathrm{x} / \text { week } \\
40 \mathrm{~min} / \mathrm{session} \\
60-70 \% \text { HRmax } \\
\text { Treadmill } \\
\text { Control group } \\
\text { Conventional } \\
\text { Physiotherapy }\end{array}$ & $\begin{array}{l}\uparrow 17 \% \text { cardiovascular } \\
\text { capacity }\end{array}$ \\
\hline Eich et $\mathrm{al}^{10}$ & $\begin{array}{l}\text { Randomized controlled } \\
\text { trial } \\
\text { - Exercise group } \\
\text { - Control group }\end{array}$ & $\begin{array}{l}\text { Acute stroke } \\
\text { Supratentorial } \\
\mathrm{N}=40 \\
\text { Age: } 50-75 \text { years } \\
\text { Male/ Female }\end{array}$ & $\begin{array}{c}6 \\
\text { weeks }\end{array}$ & $\begin{array}{l}\text { Exercise group } \\
6 \mathrm{x} / \mathrm{week} \\
30 \mathrm{~min} / \mathrm{session} \\
\text { treadmill } \\
30 \mathrm{~min} / \text { session } \\
\text { physioteherapy } \\
60 \% \mathrm{HRR} \\
\\
\text { Control group } \\
60 \mathrm{~min} / \text { session } \\
\text { Gait Bobath }\end{array}$ & $\begin{array}{l}\uparrow \text { velocity and } \\
\text { capacity to walking } \\
\uparrow 30 \% \text { performance } \\
6 \mathrm{MWT} \\
\uparrow \mathrm{VO}_{2 \text { peak }} \\
\uparrow \text { functional mobility }\end{array}$ \\
\hline Katz-Leurer et al ${ }^{23}$ & $\begin{array}{l}\text { Randomized controlled } \\
\text { trial } \\
\text { - Exercise group } \\
\text { - Control group }\end{array}$ & $\begin{array}{l}\text { Acute Stroke }(30 \\
\text { days) } \\
\mathrm{N}=92 \\
\text { Mean age }=63 \\
\text { years } \\
\text { Male/ Female }\end{array}$ & 8 weeks & $\begin{array}{l}\text { Exercise group } \\
5 \mathrm{x} / \text { week } \\
30 \mathrm{~min} / \text { session } \\
60 \% \mathrm{HRmax} \\
\text { Cycle ergometer } \\
\text { Control group } \\
\text { Conventional } \\
\text { Physiotherapy }\end{array}$ & $\begin{array}{l}\downarrow \text { rest HR } \\
\uparrow \text { load and working } \\
\text { time }\end{array}$ \\
\hline Katz-Leurer et al ${ }^{24}$ & $\begin{array}{l}\text { Randomized controlled } \\
\text { trial } \\
\text { - Exercise group } \\
\text { - Control group }\end{array}$ & $\begin{array}{l}\text { Acute stroke } \\
\text { Follow-up } 6 \\
\text { months } \\
\mathrm{N}=90 \\
\text { Mean age = } 63 \\
\text { years } \\
\text { Male/ female }\end{array}$ & $\begin{array}{c}8 \\
\text { weeks }\end{array}$ & $\begin{array}{l}\text { Exercise group } \\
5 \mathrm{x} / \text { week } \\
30 \mathrm{~min} / \text { session } \\
60 \% \text { HRmax } \\
\text { Cycle ergometer } \\
\text { Control group } \\
\text { Conventional } \\
\text { Physiotherapy }\end{array}$ & $\begin{array}{l}\text { None significant } \\
\text { difference between } \\
\text { groups in daily } \\
\text { activities, as well as } \\
\text { previous and post } \\
\text { exercise intervention. }\end{array}$ \\
\hline
\end{tabular}

HRmax (Maximal heart rate); HRR (Heart Rate Reserve); HRmax (Maximal heart rate).

Similarly, we detected a clear disparity among researchers with respect to the intensity of exercises. Six studies used fixed intensity, while in other 7 studies progressive intensities were chosen. One study did not set any intensity for training ${ }^{11}$ and another study compared three types of protocol, with 2 of them involving aerobic training, one with high intensity (60-70\%) and one with low intensity (40-70\%). ${ }^{13}$ Both duration and intensity may have been preferentially chosen because they may facilitate the adaptation of the subjects to training, minimizing discomfort and the possibility of withdrawal.

\section{CONCLUSION}

In our overall evaluation, aerobic exercise training emerged as a valuable strategy to improve cardiorespiratory capacity, often associated with significant changes in 
metabolism in post-stroke patients. The outlook seems to identify very favorable outcomes for both cardiovascular risk reduction and reduced risk of a new ischemic event. Also, the data offered a clearer understanding of the impact on functional variables provided by this training, which may be safely associated with conventional therapy or even as an alternative to it.

Exercise prescription has been hindered by the lack of standardized assessment and aerobic training protocols, which would otherwise help professionals to a fuller informed decision-making in the safe management of poststroke patients. However, the data here presented seems promising, both in terms of improved functional capacity and improved cardiovascular capacity. Further studies are needed to help standardize and expand the therapeutic tools for the treatment this population.

\section{CONFLICTS OF INTEREST}

The authors declare that there are no conflicts of interest.

\section{FUNDING SOURCES}

This research received no specific grant from any funding agency in the public, commercial, or not for-profit sectors.

\section{REFERENCES}

1. Dias D, Laíns J, Pereira A, Aunes R, Caldas J, Amaral C, et al. Can we improve gait skills in chronic hemiplegics? A randomised control trial with gait trainer. Eura Medicophys. 2007;43:499-504.

2. Peurala SH, Tarkka IM, Pitkänen K, Sivenius J. The effectiveness of body weight - supported gait training and floor walking in patients with chronic stroke. Arch Phys Med Rehabil. 2005;86:1557-64.

3. Ng MF, Tong RK, Li LS. A pilot study of randomized clinical controlled trial of gait training in subacute stroke patients with partial body-weight support, electromechanical gait trainer and functional electrical stimulation: six-month follow-up. Stroke. 2008;39:154-60.

4. Di Carlo A. Human and economic burden of stroke. Age Ageing. 2009;38:4-5.

5. Shaughnessy M, Resnick BM, Macko RF. Reliability and validity testing of the short self-efficacy and outcome expectation for exercise scales in stroke survivors. J Stroke Cerebrovasc Dis. 2004;13:214-9.

6. Roth EJ. Heart disease in patients with stroke. Part 2: Impact and implications for rehabilitation. Arch Phys Med Rehabil. 1994;75:94-101.

7. Hafer-Macko CE, Ryan AS, Ivey FM, Macko RF. Skeletal muscle changes after hemiparetic stroke and potential beneficial effects of exercise intervention strategies. J Rehabil Res Dev. 2008;45:261-72.

8. Morris $\mathrm{JH}$, Williams $\mathrm{B}$. Optimising long-term participation in physical activities after stroke: Exploring new ways of working for physiotherapists. Physiotherapy. 2009;95:227-33.

9. Hill DC, Ethans KD, Macleod DA, Harrison ER, Matheson JE. Exercise stress testing in subacute stroke patients using a combined upper- and lower-limb ergometer. Arch Phys Med Rehabil. 2005;86:1860-66.

10. Eich $\mathrm{HJ}$, Mach $\mathrm{H}$, Werner $\mathrm{C}$, Hesse $\mathrm{S}$. Aerobic treadmill plus bobath walking training improve walking in subacute stroke: a randomized controlled trail. Clin Rehabil. 2004;18:640-51.

11. Janssen TW, Beltman JM, Elich P, Koppe PA, Konijnenbelt $H$, DE Haan $A$, et al. Effects of electric stimulation assisted cycling training in people with chronic stroke. Arch Phys Med Rehabil. 2008;89:463-9.

12. Lee MJ, Kilbreath SL, Singh MF, Zeman B, Lord SR, Raymond J, et al. Comparison of effect of aerobic cycle training and progressive resistance training on walking ability after stroke: a randomized Sham exercise-controlled study. J Am Geriatr Soc. 2008;56:976-85.

13. Rimmer $\mathrm{JH}$, Rauworth AE, Wang EC, Nicola TL, Hill B. A preliminary study to examine the effects of aerobic and therapeutic (nonaerobic) exercise on cardiorespiratory fitness and coronary risk reduction in stroke survivors. Arch Phys Med Rehabil. 2009;90:407-12.

14. Shin WS, Lee SW, Lee YW, Choi SB, Chang HS. Effects of combined exercise training on balance of hemiplegic stroke patients. J Phys Ther Sci. 2011;23:639-43.

15. Globas C, Becker C, Cerny J, Lam JM, Lindemann U, Forrester LW, et al. Chronic stroke survivors benefit from high-intensity aerobic treadmill exercise: a randomized controlled trial. Neurorehabil Neural Repair. 2012;26:85-95.

16. Toledano-Zarhi A, Tanne D, Carmelia E, Katz-Leurer M. Feasibility, safety and efficacy of an early aerobic rehabilitation program for patients after minor ischemic stroke: A pilot randomized controlled trial. NeuroRehabilitation. 2011;28:85-90.

17. Ivey FM, Hafer-Macko CE, Ryan AS, Macko RF. Impaired leg vasodilatory function after stroke: adaptations with treadmill exercise. Stroke. 2010;41:2913-17.

18. Quaney BM, Boyd LA, Mcdowd JM, Zahner LH, He J, Mayo MS, et al. Aerobic exercise improves cognition and motor function poststroke. Neurorehabil Neural Repair. 2009;23:879-85.

19. Lennon O, Carey A, Gaffney N, Stephenson J, Blake C. A pilot randomized controlled trial to evaluate the benefit of the cardiac rehabilitation paradigm for the non-acute ischemic stroke population. Clin Rehabil. 2008;22:125-33.

20. Ivey FM, Ryan AS, Hafer-Macko CE, Goldberg AP, Macko RF. Treadmill aerobic training improves glucose tolerance and indices of insulin sensitivity in disabled stroke survivors : a preliminary report. Stroke. 2007;38:2752-58.

21. Katz-Leurer $M$, Shochina $M$. The influence of autonomic impairment on aerobic exercise outcome in stroke patients. NeuroRehabilitation. 2007;22:267-72.

22. Macko RF, Ivey FM, Forrester LW, Hanley D, Sorkin JD, Katzel LI, et al. Treadmill exercise rehabilitation improves ambulatory function and cardiovascular fitness in patients with chronic stroke: a randomized, controlled trial. Stroke. 2005;36:2206-11.

23. Katz-Leurer M, Carmeli E, Shochina M. The effect of early aerobic training on independence six months post stroke. Clin Rehabil. 2003;17:735-41.

24. Katz-Leurer M, Shochina, Carmeli E, Friedlander Y. The influence of early aerobic training on the functional capacity in patients with cerebrovascular accident at the subacute stage. Arch Phys Med Rehabil. 2003;84:1609-14. 


\section{Aerobic Program in Persons with Stroke: A Systematic Review \\ Acta Med Port 2014:27:108-115}

Publicado pela Acta Médica Portuguesa, a Revista Científica da Ordem dos Médicos

Av. Almirante Gago Coutinho, 151

1749-084 Lisboa, Portugal.

Tel: +351 218428215

E-mail: submissao@actamedicaportuguesa.com

www.actamedicaportuguesa.com

ISSN:0870-399X | e-ISSN: 1646-0758

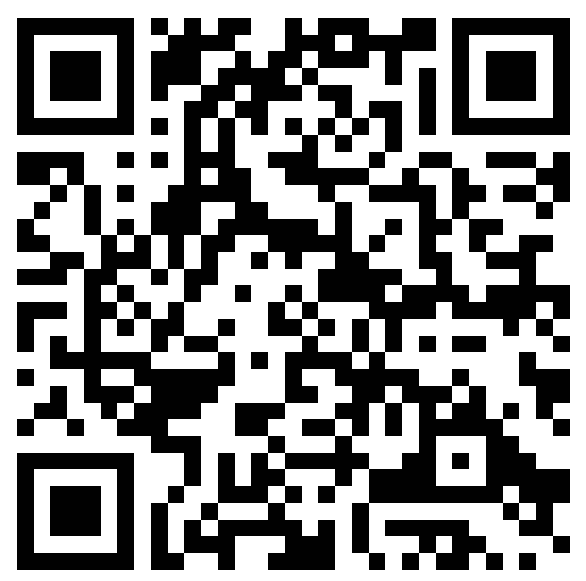

